\title{
S-type granite generation and emplacement during a regional switch from extensional to contractional deformation (Central Iberian Zone, Iberian autochthonous domain, Variscan Orogeny)
}

\author{
M. F. Pereira ${ }^{1}$ - R. Díez Fernández ${ }^{2}$ C. Gama ${ }^{3}$ - M. Hofmann ${ }^{4}$ A. Gärtner ${ }^{4}$. \\ U. Linnemann ${ }^{4}$
}

Received: 2 December 2016 / Accepted: 5 May 2017 / Published online: 19 May 2017

(c) Springer-Verlag Berlin Heidelberg 2017

\begin{abstract}
Zircon grains extracted from S-type granites of the Mêda-Escalhão-Penedono Massif (Central Iberian Zone, Variscan Orogen) constrain the timing of emplacement and provide information about potential magma sources. Simple and composite zircon grains from three samples of S-type granite were analyzed by LA-ICP-MS. New U-Pb data indicate that granites crystallized in the Bashkirian (318.7 $\pm 4.8 \mathrm{Ma})$ overlapping the proposed age range of ca. 321-317 Ma of the nearby S-type granitic rocks of the Carrazeda de Anciães, Lamego and UcanhaVilar massifs. The timing of emplacement of such S-type granites seems to coincide with the waning stages of activity of a $\mathrm{D}_{2}$ extensional shear zone (i.e. Pinhel shear zone) developed in metamorphic conditions that reached partial melting and anatexis (ca. 321-317 Ma). Dykes of two-mica granites (resembling diatexite migmatite) are concordant and discordant to the compositional layering and $\mathrm{S}_{2}$ (main) foliation of the high-grade metamorphic rocks of the Pinhel shear zone. Much of the planar fabric in these dykes was
\end{abstract}

Electronic supplementary material The online version of this article (doi:10.1007/s00531-017-1488-3) contains supplementary material, which is available to authorized users.

M. F. Pereira

mpereira@uevora.pt

1 Departamento de Geociências, ECT, Instituto D. Luiz, Universidade de Évora, Évora, Portugal

2 Departamento de Geodinámica, Instituto de Geociencias (UCM, CSIC), Universidad Complutense de Madrid, 28040 Madrid, Spain

3 Departamento de Geociências, Instituto de Ciências da Terra de Évora, ECT, Universidade de Évora, Évora, Portugal

4 Senckenberg Naturhistorische Sammlungen Dresden, Museum für Mineralogie und Geologie, Dresden, Germany formed during magmatic crystallization and subsequent solid-state deformation. Field relationships suggest contemporaneity between the ca. 319-317 Ma old magmatism of the study area and the switch from late $\mathrm{D}_{2}$ extensional deformation to early $\mathrm{D}_{3}$ contractional deformation. Inherited zircon cores are well preserved in these late $\mathrm{D}_{2}$-early $\mathrm{D}_{3}$ S-type granite plutons. U-Pb ages of inherited zircon cores range from ca. 2576 to ca. $421 \mathrm{Ma}$. The spectra of inherited cores overlap closely the range of detrital and magmatic zircon grains displayed by the Ediacaran to Silurian metasedimentary and metaigneous rocks of the Iberian autochthonous and parautochthonous domains. This is evidence of a genetic relationship between S-type granites and the host metamorphic rocks. There is no substantial evidence for the addition of mantle-derived material in the genesis of these late $\mathrm{D}_{2}$-early $\mathrm{D}_{3} \mathrm{~S}$-type granitic rocks. The $\varepsilon N d$ arrays of heterogeneous crustal anatectic melts may be just inherited from the source, probably reflecting mixing of a range of crustal materials with different ages and primary isotopic signatures. The generation of the Bashkirian S-type granites has been dominated by continental crust recycling, rather than the addition of new material from mantle sources.

Keywords Carboniferous granitic rocks $\cdot$ Igneous intrusion relationships - U-Pb zircon LA-ICP-MS dating . Migmatites $\cdot$ Crustal recycling $\cdot$ Variscan deformation

\section{Introduction}

A large extension of Carboniferous and Permian plutonic rocks crops out in the Iberian Massif (e.g., Castro et al. 2002 and references therein). In the Carboniferous, magma production occurred simultaneously with the building of 